\title{
The Development Of Public Ethics Learning Method Using Playground Song Gundul- Gundul Pacul
}

\author{
$1^{\text {st }}$ Agus Suharsono \\ BDK Yogyakarta, Jalan Solo Km. 11, Purwomartani, \\ Kalasan, Sleman, DIY \\ gusharpramudito@gmail.com
}

\author{
$2^{\text {nd }}$ Muh. Anang Al Aziz \\ BDK Yogyakarta, Jalan Solo Km. 11, Purwomartani, \\ Kalasan, Sleman, DIY \\ abdulaziz.220387@gmail.com
}

\begin{abstract}
This research aimed to find out the participants' opinion on the development of learning method using playground song Gundul-Gundul Pacul as an alternative to Public Ethics learning method in basic training and leadership education and training for prospect civil servants. This study was a Classroom Action Research according to Mertler and Charless encompassing four stages: planning, acting, developing, and reflecting. The data of research was collected using observation and questionnaire methods, and analyzed using logic inductive method. The result of research showed that the learning method was understandable, joyful, stimulating creativity, and effective. In addition, the participants argued that there was a relationship between Public Ethics and playground song GundulGundul Pacul, in which State Civil Apparatuses should work responsibly, trustworthily, and professionally to realize the objective of state. This method was recommended to be used as an alternative to Public Ethics learning in basic training and leadership education and training for prospect civil servants.
\end{abstract}

Keywords- Public Ethics; Gundul-Gundul Pacul; Learning Method; Classroom Action Research

\section{INTRODUCTION}

Minister of Administrative and Bureaucratic Reform (Indonesian: Menteri Pendayagunaan Aparatur Negara dan Reformasi Birokrasi or MenPANRB), Asman Abnur, states that governmental ethical values should be the moral foundation for state civil apparatuses organizing the government. By prioritizing ethic as high behavior standard among state executor, Indonesia is expected to realize government with a professional and reliable State Civic Apparatus (Indonesian: Aparatur Sipil Negara or ASN). The Chairperson of Election Organizer Ethic Council (Indonesian: Dewan Kehormatan Penyelenggara Pemilu or DKPP), Jimly Asshiddiqie, emphasizes on the importance of ethic application builder in government and requires MenPANRB as the Builder and ASN policy holder to be the initiator of government organizer ethic application. Actually, all of governmental, social, professional and political institutions have had ethical code, but its application has not been maximal yet as it has not been integrated and there has been no official intensive supervision by the government itself
(Menpan, 2017). People's trust in state organization is one of keys to the successful accountable government system that is free of corruption, collusion, and nepotism. For that reason, government should focus on, among others, accelerating the application of ethics among state organizer, particularly ASN, in government implementation (antaranews, 2017). A form of integrated ASN is the one implementing governmental ethics. It is in line with the consideration of Republic of Indonesia's Law Number 5 of 2014 about State Civil Apparatus (ASN Law) mentions the importance of building ASN that is integrated, professional, neutral, and free of political intervention, corruption, collusion, and nepotism practice, and can provide public service to society and can implement the role as the elements gluing nation's unity and integrity based on Pancasila and RI's Law 1945.

Considering the Chairperson of State Administration Institution's Regulations (thereafter called Perkalans) Number 18 of 2015 about Guidelines of $2^{\text {nd }}$-level Leadership Education and Training Organization, Number 20 of 2015 about Guidelines of $4^{\text {nd }}$-level Leadership Education and Training Organization, Number 21 of 2016 about Guidelines of $3^{\text {rd }}$-Grade Prospect Civil Servant (Indonesian: Calon Pegawai Negeri Sipil, thereafter called CPNS)Basic Training Organization, and Number 22 of 2016 about $2^{\text {nd }}$ and $1^{\text {st }}$-Grade Prospect Civil Servant Basic Training Organization, it can be found that Public Ethics (State Civil Apparatus/Civil Servant Ethics) is one of training and education course in $1^{\text {st }}, 2^{\text {nd }}$, and $3^{\text {rd }}$ Grades CPNS Basic Training, and the course in $4^{\text {th }}, 3^{\text {rd }}$ and $2^{\text {nd }}$ - levels leadership education and training. Based on Perkalan Number 22 of 2016 about $2^{\text {nd }}$ and $1^{\text {st }}$-Grade Prospect Civil Servant Basic Training Organization, one of components to evaluate those assuming education and training course is learning management, with subcompetency of ability of applying adult learning model. Public Ethics course is presented based on experiential learning, emphasizing on the process of internalizing those basic values, through combining interactive lecturing, discussion, case study, simulation, watching short movie, field study and 
demonstration methods (Wahyudi Kumorotomo, 2015).

This research addresses the development of learning method by applying adult learning method in Public Ethics education and training using playground song Gundul-Gundul Pacul implemented in the $3^{\text {rd }}$ period of $2^{\text {nd }}$-grade CPNS Basic Training in 2017 in Financial Education and Training Center (thereafter called BDK) of Yogyakarta. This research aims to give alternative to Public Ethics learning method in CPNS basic training and Leadership Education and Training.

\section{LITERATURE REVIEW}

\section{A. Learning Method}

Learning method can defined corresponding to its word meaning, learning and method. Method can be defined as: 1) a regular way used to do some work in order to be achieved as expected; 2) a systematic work mechanism to facilitate an activity's implementation in order to achieve the specified objective (Education and Culture Ministry, 2017).

Learning method is an attempt of giving cognitive insight, growing affective and psychomotor abilities of students by means of conceiving and implementing it. The methods can be lecturing, debriefing, demonstration, study tour, assignment, problem solving, discussion, simulation, experiment, finding, and project depending on objective, lesson material, students, environment, tool, learning source, and instructors' readiness (Nata, 2009). The use of learning method is highly determined by subject's objective, participant condition, visual aid available, facility condition in the class, time, and place, and etc. Whatever learning method chosen many not make the students unpleasant, bored, and spiritless. However, the appropriate method affects learning motivation (Mujiman, 2007). Experiential learning is the one originating from experience is very appropriate to the objective of affective and behavioral training. Experiential approach consists of six types: role playing, game and simulation, observation, mental imaging, writing assignment, and action learning project. The advantage of learning with game is, among others, that it encourages participants to deal with their own attitude and value. There are three points to be taken into account in designing the game learning method: it should be relevant to participants, the easiest way is to imitate format and character of well-known game, the instruction should be though of precisely and there should be discussion after the game to make the experience an effective teacher (Silberman, 2013).

The development of Public Ethics learning method using playground song Gundul-Gundul Pacul will give cognitive, affective, and psychomotor insights by conceiving and implementing them using a method joyful to the participants. This method belongs to action learning in which there is a relevance of action to material.

\section{B. Public Ethics Course}

The objective of Public Ethics Course is to enable the participants to inculcate values and to create attitude and behavior subjected to high public ethic standard. Meanwhile, the indicators of its success are: 1) having understanding on public officials' ethical code and behavior, 2) recognizing a variety of attitude and behavior forms in contradiction with ethical code and behavior, and the implication of ethical code and behavioral breaking to themselves, and 3) showing attitude and behavior corresponding to ethical code and behavior during Education and Training program (Wahyudi Kumorotomo, 2015).

Article 3 of State Civil Apparatus Law governs that State Civil Apparatus as a profession builds on the following principles: 1) basic values; 2) ethical and behavioral code; 3 ) commitment, moral integrity, and responsible to public service; 4) competency necessary corresponding to the assignment division; 5) academic qualification; 6) law protection guarantee in doing the duty or assignment; and 7) job professionalism. Basic value of State Civil Apparatus is governed in Article 4 of State Civil Apparatus Law including: a) holding on Pancasila ideology tightly; b) being loyal to and maintaining RI's 1945 and legal government; c) serving Indonesian people and State; d) undertaking the duty professionally and impartially; e) making decision based on specialty principle; f) creating non-discriminative work environment; g) maintaining and upholding the high ethical standard; h) being accountable for its action and performance before the public; i) having ability of implementing government policy and program; $j$ ) providing public service honestly, responsively, quickly, appropriately, accurately, expediently and decorously; k) prioritizing high-quality leadership; 1) appreciating communication, consultation, and cooperation; $\mathrm{m}$ ) prioritizing output gain and encouraging employee performance; $n$ ) encouraging equality in work; and o) improving the effectiveness of democratic government system as career system ware.

State Civil Apparatus Ethical Code and Behavioral Code in Article 5 clause (2) of State Civil Apparatus Law include: a) undertaking its duty honestly, responsibly, and with high integrity; b) undertaking its duty precisely and in disciplined manner; c) serving respectfully, decorously, and without compulsion; d) undertaking its duty in accordance with the provision of legislation; e) undertaking its duty according to the Superior or Authorized Official's order as long as it is not in contradiction with the provision of legislation and governmental ethics; f) keeping the confidentiality pertaining to state policy; g) using the state's wealth and property responsibly, effectively, and efficiently; h) preventing the conflict of interest from occurring in undertaking its duty; i) giving information correctly and not misleadingly to those needing information related to service interest; $j$ ) not misusing 
internal state information, duty, status, power, and position to get or to search for personal or others' benefit; k) holding tightly on State Civic Apparatus basic values and always maintaining the reputation and integrity of State Civic Apparatus; and 1) implementing the provision of legislation about the discipline of State Civic Apparatus. Article 5 clause (1) of State Civic Apparatus governs that ethical and behavioral codes aims to maintain State Civic Apparatus' dignity and respect.

Some studies show the importance of State Civic Apparatus ethics in undertaking its main duty, function, and responsibility. The public ethics of state officials play important position and role as a good behavioral guideline in implementing its duty. Political corruption incidence occurs due to not only the authority owned, but also the breaking of state official ethics (Djafar, 2016). Bureaucracy is inseparable from ethical values, as ethics is related to kindness and evil matters, and struggle value (Arisman, 2017). Positional ethic affects the performance of State Civil Apparatus, as indicated with understanding, conception, and implementation of State Civil Apparatus' positional ethic norms (Englin Siso, 2016). Functional relation between employee ethics and employee quality development has linear pattern and positive direction, so that the better the implementation of employee ethic, the higher is the quality of State Civic Apparatus (Areros, 2015). Implementing ethics in public administration is a must to every public administrator, as ethic functions to be public administrator's guideline and reference in undertaking its duty and authority, and to be the behavioral and action assessment standard for public administrator all at once. The good public ethic implementation is expected to grow good organizational culture and government management as well (Holilah, 2013).

\section{METHOD}

Action research, according to Mills, is the one conducted by teachers (lecturers), education organizers, counseling teachers, education advisors, or others aiming to collect information around school's work mechanism, teacher's teaching method, and students' learning method. Classroom action research has narrower and more specific theme because of limited data collection, budget and analytical competency of the author. Johnson explained three main thematic fields in classroom action research: trying the new teaching method, identifying a problem, and studying an attractive field. Meanwhile, Mertler and Charles expands theme: class situation, teaching material, class management, teaching method, relationship between human development pattern and education, ranking and evaluation, and conference. Classroom action research is intended to the interest of teachers or lecturers themselves. The research procedure was conducted in four stages consisting of nine implementation steps (Mertler, 2012), as shown in Table 1.
Table 1 Research Stages and Steps

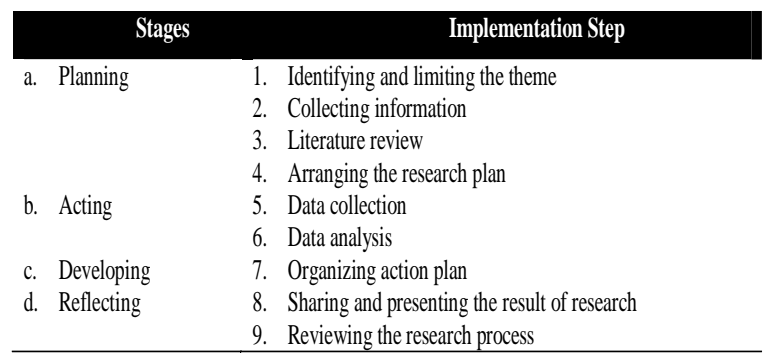

Those steps are not considered as absolute but can be reduced or repeated. Action research is a cyclical rather than linear process (Mertler, 2012).

This classroom action research was conducted on the $2^{\text {nd }}$-Grade Prospect Civil Servant (CPNS) Basic Training, the alumni of D3 PKN STAN, in the $3^{\text {rd }}$ period of 2017 in BDK Yogyakarta. The participants consisted of three classes but the study was conducted on two classes only, as the author teaches in the two classes only. Class B consisted of 33 participants: 9 males $(27 \%)$ and 24 females $(73 \%)$, while Class C consisted of 30 participants: 9 males $(30 \%)$ and 21 females $(70 \%)$.

The instrument used in qualitative research the author himself (Sugiyono, 2015). However, to collect data as much as possible and to facilitate the data collection, other instruments such as questionnaire and observation note were also employed. Data collection in this study was conducted through observing directly the learning process in $\mathrm{t}$ he class, interviewing directly, and using questionnaire, documentation, and poliangulation (more than one data). The data collected were then analyzed using logico-inductive analysis technique, the thinking process using logic to conceive data pattern and predisposition encompassing three stages: coding, describing main characteristics, and interpreting data (Mertler, 2012).

\section{FINDING AND DISCUSSION}

\section{A. Planning}

The development of Public Ethic Education and Training Course learning method was conducted using playground song Gundul-Gundul Pacul because the $2^{\text {nd }}$-Grade Prospect Civil Servant (CPNS) Basic Training should be conducted using adult education method. Playground song Gundul-Gundul Pacul is considered as popular and can be undertaken more joyfully with simple dancing. This learning method development can also meet the objective of Education and Training from cognitive, affective, and psychomotor aspects by means of joyful game. To apply the method, the simple equipment can be provided such as video of playground song dance Gundul-Gundul Pacul. Next, the participants would be asked for their opinion about the meaning of playground song Gundul-Gundul Pacul. To expand the data source, the participants are allowed to 
browse in internet. The participants that have gotten it would be told to explain the meaning of playground song Gundul-Gundul Pacul.

Gundul-Gundul Pacul is one of Central Java's local songs written by Sunan Kalijaga in 1400s. The lyric of playground song Gundul-Gundul Pacul is sufficiently short: Gundhul gundhul pacul cul gembèlengan/ Nyunggi nyunggi wakul kul gembèlengan/ Wakul ngglimpang segané dadi sak latar/. Literally, this lyric tells about a child with bald head carrying rice basket on his head, and his haphazard attitude makes the basket fall down and the rice spilled on the house yard (Suharsono, 2010). It is a very haphazard lyric when interpreted literally. However, many people believe that there is a philosophical meaning behind the lyric. Some people interpret head as honor and bald head as crown. Pacul (hoe) is the name of farming tool. But it is here interpreted as papat kang ucul or the four honors including eyes, nose, ears, and mouth. Each of them has different function: eyes are used to see the people's difficulty, ears to listen to advice, nose to smell the aroma of kindness, and mouth to say fair or just words. Gembelengan is defined as conceit, arrogance, and playfulness as the rice basket on the head symbolizes the people's mandate. Gembelengan or unreliability attitude makes wakul segane dadi sak latar, or the rice spilled on the yard (Saputra, 2016).

Playground song Gundul-gundul Pacul contains noble character education to make the child an excellent human with noble character, humility (andhap asor), no arrogance and conceit despite his/her advantages compared with others, as conceit or arrogance will be in vain and make him/her in loss (Khalim, 2011). In similar vein, Hidayah (2013) states that playground song Gundul-Gundul Paculcontains cultural meaning that if we have honor, position, and glory because we have great income, we should not be arrogant and conceited or we will fall down and will affect people surrounding adversely.

After the explanation of playground song GundulGundul Pacul, the participants are asked to identify the values contained in the song related to Public Ethic Training and Education Course. Playground song Gundul-Gundul Pacul can be related to Public Ethic Training and Education Course, in which State Civil Apparatuses have substantial mandate or trusteeship, to create people wellbeing. For that reason, they should work sincerely and not arrogantly to achieve the people wellbeing. To make the learning more joyful, each of groups is given thirty minutes to prepare choreography for playground song Gundul-Gundul Pacul. After everyone has been ready, each of groups is told to perform their dance. This activity aims to give in-depth and joyful impression to make the playground song GundulGundul Pacul memorable in long term. After the learning has been completed, the participants are given questionnaire to find out their opinion and the relationship between the song and Public Ethic Training and Education Course.

\section{B. Taking Action}

Considering the result of research, it could be found that three participants $(5 \%)$ have never sung playground song Gundul-Gundul Pacul and other sixty participants $(95 \%)$ have ever sung it. However, only two participants (3\%) have known the meaning of playground song Gundul-Gundul Pacul, and other sixty one participants (97\%) have not known yet. After the participants were told to search for the meaning of playground song Gundul-Gundul Pacul in internet and after the instructor's explanation, all participants argue that the song is related to Public Ethic Training and Education course, as presented completely in Table 2.

Table 2. Number of Participants, Ever Singing it in childhood, Knowledge on the meaning of song, and its relation to Public Ethic Training and Education Course

Source: Result of Research

\begin{tabular}{|c|c|c|c|c|c|c|}
\hline \multirow{2}{*}{ Explanation } & \multicolumn{2}{|c|}{ Class B } & \multicolumn{2}{|c|}{ Class C } & \multicolumn{2}{|c|}{ Total } \\
\hline & Number & $\%$ & Number & $\%$ & Number & $\%$ \\
\hline \multicolumn{7}{|c|}{ Sex } \\
\hline Male & 9 & $27 \%$ & 9 & $30 \%$ & 18 & $29 \%$ \\
\hline Female & 24 & $73 \%$ & 21 & $70 \%$ & 45 & $71 \%$ \\
\hline Total & 33 & $100 \%$ & 30 & $100 \%$ & 63 & $100 \%$ \\
\hline \multicolumn{7}{|c|}{ Has ever sung it in childhood } \\
\hline Ever & 30 & $91 \%$ & 30 & $100 \%$ & 60 & $95 \%$ \\
\hline Never & 3 & $9 \%$ & 0 & $0 \%$ & 3 & $5 \%$ \\
\hline Total & 33 & $100 \%$ & 30 & $100 \%$ & 63 & $100 \%$ \\
\hline \multicolumn{7}{|c|}{ Know the meaning of Song Gundul-Gundul Pacul } \\
\hline Know & 2 & $6 \%$ & 0 & $0 \%$ & 2 & $3 \%$ \\
\hline Not know & 31 & $94 \%$ & 30 & $100 \%$ & 61 & $97 \%$ \\
\hline Total & 33 & $100 \%$ & 30 & $100 \%$ & 63 & $100 \%$ \\
\hline \multicolumn{7}{|c|}{ The relation between Song and Public Ethic Material } \\
\hline Related & 33 & $100 \%$ & 30 & $100 \%$ & 63 & $100 \%$ \\
\hline Not related & 0 & $0 \%$ & 0 & $0 \%$ & 0 & $0 \%$ \\
\hline Total & 33 & $100 \%$ & 30 & $100 \%$ & 63 & $100 \%$ \\
\hline
\end{tabular}

After the explanation about the meaning of playground song Gundul-Gundul Pacul, to give indepth impression, the class is divided into six groups and each of groups is given thirty minutes to prepare choreography to perform the dance and to sing playground song Gundul-Gundul Pacul. The next step is that each of group is told to perform choreography and to sing playground song GundulGundul Pacul. Then face-to-face meeting is followed with discussing the next materials. After face-to-face meeting has been completed, the participants are asked for their opinion about Public Ethic learning method delivered by means of playground song Gundul-Gundul Pacul with Public Ethic material and writing the answer in questionnaire sheet and participants may express more than one opinion. The participants are required to express their opinion in questionnaire as well two months after the learning 
has been completed. The participants' opinions are presented in Table 3.

Table 3 Participants' opinion on Public Ethic learning method with playground song GundulGundul Pacul after Learning and Two Months after Learning

\begin{tabular}{l|cc|}
\hline \multicolumn{1}{|c|}{ Opinion } & After Learning & Two Months after Learning \\
\hline Simple but applicative & 6 & 2 \\
Good & 8 & 9 \\
Effective & 12 & 5 \\
Generating creativity & 14 & 6 \\
Joyful & 27 & 15 \\
Teaching life values & 3 & 2 \\
Understandable & 29 & 28 \\
Relevant & 3 & 8 \\
Attractive & - & 36 \\
\hline
\end{tabular}

The participants' opinion on Public Ethic learning method with playground song Gundul-Gundul Pacul after the learning is good; the most description shows that this method is understandable, joyful, generating creativity, and effective. It means that this method had been consistent with adult learning method. Two months after the learning, the participants' opinion is similar to that after the learning, with the addition of only opinion with significant value showing that the learning method is very attractive.

In addition to the questions about method, the questionnaire given to the participant questions what the participants remember about the relationship between playground song Gundul-Gundul Pacul and Public Ethics material. All participants remember the relationship between playground song GundulGundul Pacul and Public Ethic material, but express it in different words or sentences, as shown in Table 4.

Table 4 What the participants remember about the relationship between playground song GundulGundul Pacul and Public Ethic material

\begin{tabular}{|l|c|c|}
\hline Opinion & After Learning & Two months later \\
\hline Professional & 11 & 11 \\
Public Service & 8 & 17 \\
Responsible & 46 & 16 \\
Having integrity & 2 & 2 \\
Ethical & 3 & 7 \\
Trustworthy & 24 & 29 \\
Careful & - & 8 \\
Leadership & - & 1 \\
\hline
\end{tabular}

The participants' answers to the question "What the participants remember about the relationship between Public Ethic material and playground song Gundul-Gundul Pacul are dominantly: responsible, trustworthy, and professional. Ninety five percents participants have ever sung playground song GundulGundul Pacul during childhood and still remember it until adulthood. However, only $3 \%$ of them have known the relationship playground song GundulGundul Pacul and Public Ethic material and the meaning of it. This song's meaning has been inculcated into the participants' memory and the addition of meaning during the learning can give new meaning that will be memorable in long term as well. Just like other playground songs that will be remembered until adulthood, the meaning of it will be remembered until adulthood as well. Thus, the participants are expected to remember their duty as State Civil Apparatuses responsible for the mandate of achieving the state's objective professionally, because when they do not do so sincerely, they will drop the rice basket (wakul nasi) existing on their head. Two months after the learning, the participants' opinions are similar to those after the learning, with the addition of two opinions with not too significant values: being careful (in working) and leadership.

\section{Developing and Reflecting}

Although positive opinions are dominant, one participant argues that a class should be divided into two or three groups only rather than six groups to shorten the duration of performance. This opinion is fairly logical and reasonable, so that if this method is used, the class should be divided into three groups to perform the choreography of playground song Gundul-Gundul Pacul to give more time to develop and to explore playground song Gundul-Gundul Pacul with Public Ethic material.

\section{CONCLUSION}

The result of research and development of Public Ethic learning method with playground song GundulGundul Pacul, considering the participants' opinion after learning and two months after learning, shows that the method is understandable, joyful, generating creativity, and effective. Meanwhile, the participants' opinion about the relationship between Public Ethic and playground song Gundul-Gundul Pacul included responsible, trustworthy, and professional. Many participants have known the playground song GundulGundul Pacul, but many of them have not known yet its meaning, when related to Public Ethic material. This learning method can be used by changing the class into three groups rather than six groups to give sufficient time to develop and to reflect its meaning.

\section{REFERENCES}

[1] antaranews. (2017, 06 19). antaranews.com. Retrieved from berita: http://www.antaranews.com/berita/622515/menpan-rbetika-pemerintahan-landasan-moral-asn

[2] Areros, W. A. (2015). Pengaruh Etika Administrasi Terhadap Pengembangan Kualitas Sumber Daya Manusia Pegawai Negeri Sipil (Pada Kantor Kecamatan Pinolosian Kabupaten Bolaang Mongondouw Selatan) . Acta Diurna, 9.

[3] Arisman. (2017, 06 21). kemenkumham.go.id. Retrieved from karya ilmiah: https://jakarta.kemenkumham.go.id/download/karya- 
ilmiah/pelayanan-publik/70-etika-aparatur-dalampelayanan-publik/file

[4] Djafar, M. N. (2016). Etika Publik Pejabat Negara dalam Penyelenggaraan Pemerintahan yang Bersih. Jurnal Politik, 1757.

[5] Englin Siso, J. R. (2016). Pengaruh Etika Jabatan Terhadap Kinerja Aparatur Sipil Negara Disekertariat Kota Manado . Jurnal Administrasi Publik, 8.

[6] Hidayah, A. (2013). Makna Budaya Lagu Dolanan di Jawa Tengah. Jurnal Pendidikan, 33-46.

[7] Holilah. (2013). Etika Administrasi Publik. Jurnal Review Politik, 232-255.

[8] Kemdikbud. (2017, September 03). kbbi.kemdikbud.go.id. Retrieved from kbbi.kemdikbud.go.id:

https://kbbi.kemdikbud.go.id/entri/metode

[9] Kemendikbud. (2017, September 03). kbbi.kemdikbud.go.id. $\quad$ Retrieved from kbbi.kemdikbud.go.id: https://kbbi.kemdikbud.go.id/entri/pembelajaran

[10] Khalim, S. (2011). Etika Islam Jawa Dalam Tembang Gundul-Gundul Pacul. Ibda, 126-136.
[11] Menpan. (2017, 06 19). menpan.go.id. Retrieved from berita terkini: https://www.menpan.go.id/beritaterkini/6681-pentingnya-etika-asn-dalam-menjagakepercayaan-publik-terhadap-pemerintah

[12] Mertler, C. A. (2012). Action Research. Yogyakarta: Pustaka Pelajar.

[13] Mujiman, H. (2007). Manajemen Pelatihan Berbasis Belajar Mandiri. Yogyakarta: Pustaka Pelajar.

[14] Nata, A. (2009). Perspektif Islam Tentang Strategi Pembelajaran. Jakarta: Kencana.

[15] Saputra, M. I. (2016). Pemimpin Ideal Dalam Perspektif Syair Gundul-Gundul Pacul . Al-Tadzkiyyah, 299-311.

[16] Silberman, M. (2013). Active Training, Pedoman Praktis tentang Teknik, Desain, Contoh Kasus, dan Kiat. Bandung: Nusa Media.

[17] Sugiyono. (2015). Metode Penelitian Pendidikan. Bandung: Alfabeta.

[18] Suharsono, A. (2010). Jaman Penjor. Yogyakarta: Leutika.

[19] Wahyudi Kumorotomo, N. R. (2015). Etika Publik. Jakarta: LAN. 